\title{
Penerapan Metode AHP dan OCRA dalam Pengambilan Keputusan Menentukan Santri Berprestasi
}

\author{
Mochammad Ichsan*1, Putri Aisyiyah Rakhma Devi ${ }^{2}$ \\ ${ }^{1,2}$ Program Studi Teknik Informatika, Universitas Muhammadiyah Gresik \\ mochammadichsan002@gmail.com*1, deviaisyiyah@umg.ac.id ${ }^{2}$
}

(Received: 30 Oktober 2021 / Accepted: 24 November 2021 / Published Online: 20 Desember 2021)

\begin{abstract}
Abstrak
Pemilihan santri berprestasi merupakan apresiasi yang diberikan oleh pondok kepada para santri yang memiliki nilai tertinggi. Namun dalam pemilihan biasanya masih dilakukan secara subjektif dan manual, dan tidak adanya sistem pendukung dalam mengambil keputusan yang menjadikan proses pemilihan menjadi lama dan kurang tepat. Penelitian ini bertujuan untuk menerapkan sistem pendukung keputusan dalam menentukan santri berprestasi di Pondok Pesantren Mamba'ussholihin dengan kriteria yang sudah ditentukan sebelumnya. Proses pemilihan santri berprestasi menggunakan menggunakan metode Analytical Hierarchy Process (AHP) untuk pembobotan kriteria dan Operational Competitiveness Rating Analysis (OCRA) untuk perangkingan. Nilai OCRA yang didapat berupa nilai $P i$ yang di rangking untuk mendapatkan santri terbaik. Hasil temuan menunjukan bahwa tingkat konsistensi kesalahan kurang dari 10\% dan nilai indeks konsistensi diterima, sehingga dapat digunakan sebagai bobot awal dengan jumlah relatif bobot awal $=1$. Setelah dilakukan perhitungan pada metode OCRA dari 75 data alternatif awal didapatkan 10 data alternatif teratas yang didapat berupa nilai $P i$ nantinya berhak mendapatkan penghargaan sebagai santri berprestasi, sehingga dengan menerapkan kedua metode ini dapat mempercepat hasil keputusan, tidak memakan waktu yang lama dan hasil yang didapat juga tepat.
\end{abstract}

Kata kunci: Analytical Hierarchy Process, Berprestasi, Operational Competitiveness Rating Analysis, Sistem Pendukung Keputusan

\begin{abstract}
The selection of outstanding students is an appreciation given by the boarding school to the students who have the highest scores. However, the election is usually still done subjectively and manually, and there is no support system in creating decisions, which make the selection process long and inaccurate. This study aims to implement a decision support system in determining outstanding students at Mamba'ussholihin Islamic Boarding School predetermined with criteria. The process of selecting uses the method Analytical Hierarchy Process (AHP) for weighting criteria and Operational Competitiveness Rating Analysis (OCRA) for ranking. The OCRA value obtained is in the form of Pi, which is ranked to get the best students. The findings show that the error consistency level is less than $10 \%$ and the consistency index value is accepted, so that it can be used as an initial weight with a relative number $=1$. After calculating the OCRA method from the initial 75 alternative data, the top 10 alternative data obtained are in the form of the value of Pi will be entitled to an award as an outstanding student, so by applying these two methods it can speed up the results of the decision, it does not take a long time and the results obtained are also precise.
\end{abstract}

Keywords: Analytical Hierarchy Process, Achievement, Decision Support System, Operational Competitiveness Rating Analysis.

\section{PENDAHULUAN}

Di era globalisasi pengunaan teknologi sangat berpengaruh kepada perkembangan di masyarakat ataupun di sebuah organisasi. Pengunaan alat bantu komputer sebagai media penerima data, pengelola data dan penyimpanan data sudah tidak diragukan lagi. Sistem 
Pendukung Keputusan saat ini sangat dibutuhkan dalam mendukung setiap tahapan pengambilan keputusan di organisasi, mulai dari mengindentifikasi atau menganalisa masalah, menentukan data yang relevan dan menggunakan pendekatan yang digunakan dalam proses pengambilan contohnya dalam hal memberi keputusan (Amiruddin et al., 2018).

Dalam melakukan pengambilan keputusan di suatu organisasi, pasti ada permasalahan yang sering kali timbul. Permasalahan yang umum dilakukan adalah kurang efektifnya penentuan keputusan dan kurang efeisien karena masih bersifat subjektif. Sama halnya yang dilakukan di Pondok Pesantren Mamba'ussholihin dalam penentuan santri berprestasi. Kegiatan pemilihan santri berprestasi dilakukan Pondok Pesantren Mamba'ussholihin untuk memberikan apresiasi kepada santri yang memiliki nilai teratas. Dalam pemilihan santri berprestasi biasanya dilakukan dengan rumus perhitungan total dari pesantren dan tes wawancara dengan ketentuan yang sudah ada, lalu diambil dari total akhir test teratas. Masalah timbul ketika calon peserta pemilihan santri terbaik yang mendaftar dan memenuhi syarat yang ditetapkan melebihi jumlah yang dibutuhkan. Hal tersebut menyebabkan panitia seleksi sulit membandingkan nilai santri terbaik sesuai dengan syarat dan ketentuan sehingga pelaporan akan perlu waktu yang cukup lama. Disini peran Sistem Pendukung Keputusan dibutuhkan dan bisa menjadi solusi untuk pengambilan sebuah keputusan dalam menentukan santri berprestasi yang tepat, serta menjadi alat bantu bagi para pengambil keputusan untuk menentukan santri berprestasi serta sesuai dengan kriteria yang diinginkan Pondok Pesantren.

Sistem Pendukung Keputusan biasanya dibangun untuk mendukung solusi atas suatu masalah atau untuk suatu peluang. SPK dapat juga didefinisikan sebagai sistem basis model yang terdiri dari prosedur-prosedur dalam pemrosesan data yang pertimbangannya untuk membantu manajer dalam mengambil keputusan. Dalam sistem pendukung keputusan tersebut terdapat banyak metode atau bahkan model yang bisa digunakan. Untuk penelitian kali ini kami mengunakan metode Analytical Hierarchy Process (AHP) dan Operational Competitiveness Rating Analysis (OCRA), AHP adalah metode tentang pengukuran yang dipakai untuk menetukan skala rasio dengan melakukan perbandingan berpasangan setiap faktor. Perbandingan berpasangan dapat ditentukan melalui intuisi, pengukuran aktual maupun pengukuran relatif, derajat kepentingan, tingkat kesukaan, pengalaman maupun fakta seseorang yang dijadikan skala dasar yang memperlihatkan kekuatan dan preferensi realtif (Hasanudin, Marli, \& Hendriawan, 2018). Sedangkan OCRA adalah pendeketan pengukuran kinerja relatif berdasarkan sebuah model nonparametrik. Metode OCRA merupakan metode yang sangat berguna dan sederhana untuk menganalisis sektor yang berbeda dan membandingkan unit keputusan yang berbeda. Metode ini pertama kali diusulkan untuk menyelesaikan masalah penilaian kinerja dan analisis produktivitas, namun belakangan ini juga digunakan untuk menyelesaikan berbagai masalah dalam literatur studi yang menerapkan metode OCRA untuk bidang yang berbeda (Toruan, 2021).

Adapun penelitian-penelitian yang telah menggunakan metode AHP dalam mengambil keputusan terkait dengan permasalahan yang ada pada bidang yang berbeda-beda diantaranya (Agustina et al., 2021; Chamid \& Murti, 2017; Irawati, 2018; Narti et al., 2019; Pane \& Erwansyah, 2020; Primadasa \& Alfiarini, 2019; Ramadhan \& Santika, 2020), sementara yang menerapkan metode OCRA diantaranya (Kundakc1, 2017; Madić et al., 2015; Mesran et al., 2019).

Berdasarkan hal tersebut di atas, beberapa peneliti sebelumnya yang telah menerapkan metode AHP maupun OCRA untuk proses pengambilan keputusan pada bidang yang berbedabeda. Pada penelitian ini berfokus untuk menerapkan sistem pendukung keputusan untuk menentukan santri terbaik dengan mengkombinasikan metode Analytical Hierarchy Process dan Operational Competitiveness Rating Analysis serta kriteria yang sudah ditentukan. Metode AHP digunakan untuk menentukan bobot awal kriteria, sedangkan metode OCRA digunakan 
untuk perangkingan pada data alternatif berupa santri yang diharapkan dapat membantu dalam pengambilan keputusan yang bertujuan untuk menentukan santri terbaik.

\section{METODE}

Jenis penelitian ini adalah kuantitatif dengan mengunakan data alternatif yang didapatkan melalui proses test yang dilakukan oleh pihak pondok pesantren sedangkan untuk mendapatakan kriteria peneliti melakukan diskusi/wawancara dengan pihak yang terkait dan nantinya akan dilakukan perhitungan menggunakan metode AHP untuk penentuan bobot setiap kriteria dan Metode OCRA untuk perangkingan sampai hasil dan pembahasan.

Pada tahapan pengumpulan data, data alternatif yang digunakan untuk penelitian ini berasal dari proses test yang dilakukan para santri yang mendaftarkan. Data ini memiliki 5 kriteria dasar yaitu Baca Al-Quran (K1), Baca Kitab Kuning (K2), Bahasa Arab (K3), Bahasa Inggris (K4), dan Hafalan 30 Juz (K5) dengan semua kriteria berjenis benefit. Data alternatif yang didapat setelah dilakukannya test oleh para santri dan diskusi peneliti dengan pihak terkait didapatkan sejumlah 75 data beserta kriteria yang dijadikan subjek penelitian.

Metode yang digunakan pada penelitian ini menggunakan Analytical Hierarchy Process (AHP) sebagai penentuan bobot kriteria pada data alternatif, dimana untuk mendapatkan bobot pada proses AHP perhitungan dimulai dari membuat matrik perbandingan yang mana penetuannya didapatkan dari hasil diskusi dengan pihak terkait berdasarkan skala Saaty yang terlihat pada tabel 1. Setelah didapatkan matriks perbandingan berpasangan, dilanjutkan dengan menormalisasikan data dengan membagi data dari setiap elemen dengan nilai total dari setiap kolom. Selanjutnya akan di hitung Nilai Consistency Indeks dan Consistency Rasio dengan ketentuan perhitungan perbandingan berpasangan dapat diterima dan konsisten apabila hasil perhitungan CR / Consistency Rasio $\leq 0$.1. Jika perhitungan perbandingan berpasangan diterima maka nilai prioritas pada perhitungan AHP akan digunakan sebagi bobot untuk masing-masing kriteria. Pada tahapan perangkingan menggunakan metode Operational Competitiveness Rating Analysis (OCRA), metode ocra dimulai dari tahapan pembuatan matriks keputusan kemudian dilakukan perihitungan peringkat preferensi dan peringkat preferensi linier. Pada tahapan peringkat preferensi perhitungan yang dilakukan hanya menggunakan tahapan untuk peringkat preferensi yang akan di maximalkan (benefit) karena kriteria yang didapatkan tidak ada yang akan di minimalkan (cost), lalu yang terakhir menghitung total nilai preferensi utnuk setiap alternatif. Dari total perhitungan tersebut akan dirangking berdasarkan nilai yang terbesar. Teknik analisis data yang digunakan pada penelitian ini yaitu teknik analisis deskriptif dengan mencari nilai persentasi dari tiap indikator instrumen.

\section{HASIL DAN PEMBAHASAN Hasil}

Dalam melakukan penentuan santri berprestasi pondok pesantren sebelumnya mengunakan dengan cara konvensional akan di ganti dengan sistem pendukung keputusan dengan metode AHP dan OCRA. Maka dilakukan penentuan kriteria dengan cara diskusi dengan pihak yang terkait dan ditentukan dengan 5 kriteria yakni : Baca Al-Quran (K1), Baca Kitab Kuning (K2), Bahasa Arab (K3), Bahasa Inggris (K4), dan Hafalan 30 Juz (K5) dengan semua data berjenis benefit seperti pada tabel 1. Dalam melakukan perhitungan penentuan santri berprestasi dengan alat bantu Microsoft Excel di berikan nilai-nilai untuk setiap data alteratif atau kandidat santri berprestasi yang terdapat 75 data alternatif yang di inisialkan dengan huruf A seperti yang dicantumkan pada tabel 2. 
Tabel 1. Skala Pebandingan Berpasangan

\begin{tabular}{ccc}
\hline Kode Kriteria & Nama Kriteria & Jenis \\
\hline K1 & Baca Al-Quran & Benefit \\
K2 & Baca kitab kuning & Benefit \\
K3 & Bahasa Arab & Benefit \\
K4 & Bahasa Inggris & Benefit \\
K5 & Hafalan Juz & Benefit \\
\hline
\end{tabular}

Tabel 2. Data Alternatif

\begin{tabular}{cccccc}
\hline $\begin{array}{c}\text { Kode } \\
\text { Alternatif }\end{array}$ & $\begin{array}{c}\text { Baca Al } \\
\text { Qur' An }\end{array}$ & $\begin{array}{c}\text { Baca Kitab } \\
\text { Kuning }\end{array}$ & $\begin{array}{c}\text { Bahasa } \\
\text { Arab }\end{array}$ & $\begin{array}{c}\text { Bahasa } \\
\text { Inggris }\end{array}$ & $\begin{array}{c}\text { Hafalan } \\
\text { Juz 30 }\end{array}$ \\
\hline A1 & 83 & 74 & 90 & 83 & 85 \\
A2 & 75 & 80 & 86 & 75 & 80 \\
A3 & 89 & 83 & 77 & 84 & 83 \\
A4 & 90 & 75 & 85 & 90 & 84 \\
A5 & 96 & 88 & 77 & 83 & 90 \\
A6 & 73 & 80 & 87 & 71 & 70 \\
A7 & 75 & 89 & 75 & 95 & 82 \\
A8 & 87 & 77 & 86 & 80 & 82 \\
& $\ldots$. & $\ldots$. & $\ldots$. & $\ldots$. & $\ldots$ \\
A75 & 78.00 & 90.00 & 83 & 87 & 76 \\
\hline
\end{tabular}

\section{Perhitungan Metode Analytical Hierarchy Prosess (AHP)}

Pada metode AHP dalam pembobotan berdasarkan diskusi terhadap pihak yang terkait menghasilkan matriks perbandingan berpasangan pada masing masing kriteria. Matriks perbandingan kriteria, diterjemahkan berdasarkan skala Saaty, dan selanjutnya dilakukan normalisasi dengan membagi tiap nilai alternatif dengan jumlah dari seluruh nilai alternatif berdasarkan kriteria. Pada tabel 3 disajikan untuk matriks perbandingan berpasangan sedangkan matriks perbandingan berpasangan dalam skala Saaty dapat lihat pada tabel 4 dan untuk hasil normalisasi matriks perbandingan berpasangan pada tabel 5.

Tabel 3. Matriks Perbandingan Berpasangan

\begin{tabular}{cccccc}
\hline & K1 & K2 & K3 & K4 & K5 \\
\hline K1 & - & Sama & Moderat & Sama & Sama \\
& & Pentingnya & Pentingnya & Pentingnya & Pentingnya \\
K2 & & - & Moderat & Moderat & Sama \\
& & & Pentingnya & Pentingnya & Pentingnya \\
K3 & & & - & Moderat & Moderat \\
& & & & Pentingnya & Pentingnya \\
K4 & & & & - & Sangat \\
& & & & Kuat \\
K5 & & & & & Pentingnya \\
\hline
\end{tabular}

Matriks perbandingan berpasangan kemudian diterjemahkan berdasarkan skala Saaty yang ditampilkan pada tabel 4. 
Tabel 4. Matriks Perbandingan Berpasangan dalam Skala Saaty

\begin{tabular}{cccccc}
\hline & K1 & K2 & K3 & K4 & K5 \\
\hline K1 & 1 & 1 & 3 & 1 & 1 \\
K2 & $1 / 1$ & 1 & 3 & 3 & 1 \\
K3 & $1 / 3$ & $1 / 3$ & 1 & 3 & 3 \\
K4 & $1 / 1$ & $1 / 3$ & 0,3 & 1 & 7 \\
K5 & $1 / 1$ & 1 & 0,3 & 0,14 & 1 \\
Total & 4,33 & 3,67 & 7,67 & 8,14 & 13,00 \\
\hline
\end{tabular}

Tabel 5.Normalisasai Matriks Perbandingan Berpasangan

\begin{tabular}{rrrrrrrl}
\hline & K1 & K2 & K3 & K4 & K5 & Jmlh & Prioritas \\
\hline K1 & 0,231 & 0,273 & 0,391 & 0,123 & 0,077 & 1,095 & 0,219 \\
K2 & 0,231 & 0,273 & 0,391 & 0,368 & 0,077 & 1,340 & 0,268 \\
K3 & 0,077 & 0,091 & 0,130 & 0,368 & 0,231 & 0,897 & 0,179 \\
K4 & 0,231 & 0,091 & 0,043 & 0,123 & 0,538 & 1,026 & 0,205 \\
K5 & 0,231 & 0,273 & 0,043 & 0,018 & 0,077 & 0,641 & 0,128 \\
\hline
\end{tabular}

Hasil normalisasi yang terlihat pada tabel 5, dihasilkan Consistency Indeks $=-0,812$ dan Consistency Rasio = -0,725, karena CR atau Consistency Rasio kurang dari 0.10 sehingga pembobotan pada setiap kriteria termasuk konsisten dan dapat dilanjutkan pada metode OCRA dengan bobot awal yang disajikan pada tabel 6 .

Tabel 6. Bobot awal

\begin{tabular}{cc}
\hline Kode Kriteria & Bobot \\
\hline K1 & 0,219 \\
K2 & 0,268 \\
K3 & 0,179 \\
K4 & 0,205 \\
K5 & 0,128 \\
Total & 1 \\
\hline
\end{tabular}

\section{Perhitungan Metode Operational Competitiveness Rating Analysis (OCRA)}

Selanjutnnya, setelah dilakukan menentukan bobot awal, tahapan perangkingan akan dilakukan mengunakan metode OCRA. Dimana hasil dari perhitungan bobot awal yaitu : Baca Al-Quran $(\mathrm{K} 1)=0,219$, Baca Kitab Kuning $(\mathrm{K} 2)=0,268$, Bahasa Arab $(\mathrm{K} 3)=0,179$, Bahasa Inggris $(\mathrm{K} 4)=0,205$, dan Hafalan $30 \mathrm{Juz}(\mathrm{K} 5)=0,128$ dan jika dijumlahkan mendapatkan hasil relative bobot awal $=1$. Berdasarkan hasil tersebut kita dapat menyelesaikan metode OCRA dengan mentransformasikan data alternatif pada tabel 2 kedalam sebuah matriks keputusan yang dapat dilihat pada tabel 7, dan dilanjutkan dengan menghitung peringkat preferensi dimana yang dihitung hanya nilai kinerja dari alternatif untuk kriteria yang akan dimaximalkan (benefit) lalu menjumlah setiap alternatif untuk mencari nilai min $\bar{O}$, hasil perhitungan dapat dilihat pada tabel 8. Dikarenakan data berjenis benefit saja, maka pada tahapan perhitungan peringkat preferensi dimana yang dihitung hanya nilai kinerja dari alternatif untuk kriteria yang akan diminimalkan (cost) tidak dilakukan.

Setelah perhitungan peringkat peringkat preferensi dimana yang dihitung hanya nilai kinerja dari alternatif untuk kriteria yang akan dimaximalkan (benerfit) tahapan selanjutnya ialah menghitung peringkat preferensi linier dari setiap alternatif, dimana hasil jumlah dari perhitungan preferensi pada setiap alternatif akan dikurang dengan nilai terkecil peringkat preferensi itu sendiri dapat dilihat pada tabel 8. Selanjutnya dilakukan menghitung total nilai preferensi untuk setiap alternatif dapat dilihat pada tabel 9. 
Tabel 7. Matriks Keputusan

\begin{tabular}{ccccc}
\hline $\begin{array}{c}\text { Baca Al } \\
\text { Qur' An }\end{array}$ & $\begin{array}{c}\text { Baca Kitab } \\
\text { Kuning }\end{array}$ & $\begin{array}{c}\text { Bahasa } \\
\text { Arab }\end{array}$ & $\begin{array}{c}\text { Bahasa } \\
\text { Inggris }\end{array}$ & $\begin{array}{c}\text { Hafalan } \\
\text { Juz 30 }\end{array}$ \\
\hline 83 & 74 & 90 & 83 & 85 \\
75 & 80 & 86 & 75 & 80 \\
89 & 83 & 77 & 84 & 83 \\
90 & 75 & 85 & 90 & 84 \\
96 & 88 & 77 & 83 & 90 \\
73 & 80 & 87 & 71 & 70 \\
75 & 89 & 75 & 95 & 82 \\
87 & 77 & 86 & 80 & 82 \\
$\ldots$. & $\ldots$. & $\ldots$. & $\ldots$. & $\ldots$ \\
78,00 & 90,00 & 83 & 87 & 76 \\
\hline
\end{tabular}

Tabel 8. Hasil Peringkat Preferensi yang akan di maksimalkan (benefit)

\begin{tabular}{ccccccc}
\hline & $\mathbf{K 1}$ & $\mathbf{K 2}$ & $\mathbf{K 3}$ & $\mathbf{K 4}$ & $\mathbf{K 5}$ & $\mathbf{J m l h}$ \\
\hline $\mathbf{A 1}$ & 0,0300 & 0,0194 & 0,0616 & 0,0609 & 0,0535 & 0,2254 \\
$\mathbf{A 2}$ & 0,0060 & 0,0427 & 0,0509 & 0,0353 & 0,0428 & 0,1777 \\
$\mathbf{A 3}$ & 0,0480 & 0,0544 & 0,0268 & 0,0642 & 0,0492 & 0,2425 \\
$\mathbf{A 4}$ & 0,0510 & 0,0233 & 0,0482 & 0,0834 & 0,0513 & 0,2572 \\
$\mathbf{A 5}$ & 0,0690 & 0,0738 & 0,0268 & 0,0609 & 0,0641 & 0,2947 \\
$\mathbf{\ldots}$ & $\ldots$ & $\ldots$ & $\ldots$ & $\ldots$ & $\ldots$ & $\ldots$ \\
$\mathbf{A 7 5}$ & 0,0150 & 0,0816 & 0,0429 & 0,0738 & 0,0342 & 0,2474 \\
& & & & & Min & $\mathbf{0 , 1 3 8 4}$ \\
\hline
\end{tabular}

Berdasarkan hasil pada tabel 11, Nampak bahwa santri yang memiliki nilai paling tinggi dan memperoleh rangking 1 adalah santri dengan kode A62 dengan total nilai preferensi sebesar 0,1888 dan rangking 75 adalah santri dengan kode A44 dengan total nilai preferensi sebesar 0,000 .

Tabel 9. Hasil Peringkat Preferensi Linier yang akan di maksimalkan (benefit)

\begin{tabular}{cccc}
\hline Alternatif & $\overline{\boldsymbol{O}}$ & $\min \overline{(\boldsymbol{O})}$ & $\overline{\overline{\boldsymbol{O}}}$ \\
\hline $\mathbf{A 1}$ & 0,2254 & 0,1384 & 0,0870 \\
$\mathbf{A 2}$ & 0,1777 & 0,1384 & 0,0392 \\
$\mathbf{A 3}$ & 0,2425 & 0,1384 & 0,1041 \\
$\mathbf{A 4}$ & 0,2572 & 0,1384 & 0,1188 \\
$\mathbf{A 5}$ & 0,2947 & 0,1384 & 0,1562 \\
$\mathbf{\ldots}$ & $\ldots \ldots$ & $\ldots$ & \\
$\mathbf{A 7 5}$ & 0,2474 & 0,1384 & 0,1090 \\
\hline
\end{tabular}

\section{Pembahasan}

Berdasarkan hasil yang didapat, dalam penerapan metode AHP dan OCRA ini mengunakan alat bantu Ms.Excel ini terdapat data informasi yang harus dimasukan pada masih masing metode. Pada metode AHP informasi yang harus dimasukan antara lain : 5 data kriteria yakni Baca Al-Quran , Baca Kitab Kuning, Bahasa Arab, Bahasa Inggris, dan Hafalan 30 Juz. Dari 5 kriteria itu akan dilakukan proses perhitungan dengan metode AHP yang di mulai dari penentuan matriks perbandingan yang diterjemahkan berdasarkan skala Saaty, hingga didapatkan nilai Consistency Rasio sebesar -0,725 yang berarti CR atau Consistency Rasio $\leq$ 
0.10 dan dapat dinyatakan konsisten atau diterima. Jika $\mathrm{CR} \geq 0,10$ berarti hasil tidak konsisten saat menepatkan skala perbandingan dan harus diulang kembali sampai hasil data kosisten (Padmowati, 2009). Hasil ini sejalan dengan penelitian yang telah dilakukan oleh (Agustina et al., 2021; Hasanudin et al., 2018; Hidayat et al., 2020; Irawati, 2018; Madić et al., 2015; Hasanudin, \& Marli, 2018; Narti et al., 2019) bahwa perhitungan yang dikembangkan sudah kosisten dan sesuai dengan apa yang dibutuhkan.

Tabel 10. Hasil Total Nilai Preferensi

\begin{tabular}{cccc}
\hline Alternatif & $\overline{\overline{\boldsymbol{O}}}_{i}$ & $\min \left(\overline{\overline{\boldsymbol{O}_{\boldsymbol{\imath}}}}\right)$ & $P_{i}$ \\
\hline $\mathbf{A 1}$ & 0,0870 & 0 & 0,0870 \\
$\mathbf{A 2}$ & 0,0392 & 0 & 0,0392 \\
$\mathbf{A 3}$ & 0,1041 & 0 & 0,1041 \\
$\mathbf{A 4}$ & 0,1188 & 0 & 0,1188 \\
$\mathbf{A 5}$ & 0,1562 & 0 & 0,1562 \\
$\ldots \ldots$ & $\ldots$ & $\ldots$ & \\
$\mathbf{A 7 5}$ & 0,1090 & 0 & 0,1090 \\
\hline
\end{tabular}

Tabel 11. Hasil Setelah Dilakukan Perangkingan

\begin{tabular}{ccc}
\hline Kode Alternatif & $P_{i}$ & Rangking \\
\hline $\mathbf{A 6 2}$ & 0,1888 & 1 \\
$\mathbf{A 2 7}$ & 0,1781 & 2 \\
$\mathbf{A 1 8}$ & 0,1658 & 3 \\
A15 & 0,1568 & 4 \\
A5 & 0,1562 & 5 \\
$\ldots .$. & $\ldots, 000$ & 75 \\
\hline $\mathbf{A 4 4}$ & 0 \\
\hline
\end{tabular}

Dari hasil pembobotan AHP yang sudah dinyatakan konsisten didapat nilai bobot awal adalah: Baca Al-Quran $(\mathrm{K} 1)=0,219$, Baca Kitab Kuning $(\mathrm{K} 2)=0,268$, Bahasa Arab = 0,179 ,Bahasa Inggris $(\mathrm{K} 3)=0,205$, dan Hafalan $30 \mathrm{Juz}(\mathrm{K} 5)=0,128$ yang jika dijumlah $=1$. Hal ini menunjukkan bahwa perhitungan ini dapat menentukan santri berprestasi untuk pondok pesantren dan proses pemilihan akan berlangsung secara objektif serta sesuai dengan kriteria yang sudah ditentukan pondok pesantren. Hal ini sejalan dengan penelitian yang dilakukan oleh (Arsyad, 2019; Handayani \& Muzakir, 2018; Rosiska, 2018) yang mana penelitian mereka menunjukkan bahwa proses pemilihan secara objektif sudah sesuai dengan kriteria dan penilaian pada perhitungan tersebut.

Tabel 12. Hasil Peringkat Terbaik.

\begin{tabular}{ccc}
\hline Kode Alternatif & $P_{i}$ & Rangking \\
\hline $\mathbf{A 6 2}$ & 0,1888 & 1 \\
A27 & 0,1781 & 2 \\
$\mathbf{A 1 8}$ & 0,1658 & 3 \\
A15 & 0,1568 & 4 \\
A5 & 0,1562 & 5 \\
A58 & 0,1390 & 6 \\
A13 & 0,1386 & 7 \\
A9 & 0,1359 & 8 \\
A52 & 0,1345 & 9 \\
$\mathbf{A 4 3}$ & 0,1338 & 10 \\
\hline
\end{tabular}


Hasil perhitungan metode AHP yang telah dilakukan, akan dipakai pada metode OCRA dengan informasi yang harus dimasukan selain bobot awal dari perhitungan AHP ialah data alternatif yang berjumlah 75 data beserta dengan nilai pada masing-masing kriteria. Dari datadata tersebut dilakukan proses perhitungan dengan metode OCRA, maka didapat peringkat preferensi pada setiap alternatif dengan 10 data teratas yang terlihat pada tabel 10 yang nantinya akan mendapatkan penghargaan sebagai santri berprestasi. Hasil untuk menentukan peringkat terdapat pada kolom $P_{i}$ dapat dilihat pada tabel 11.

\section{SIMPULAN}

Pengambilan keputusan dalam pemilihan santri berprestasi sudah dapat menggunakan penerapan metode AHP dan OCRA sehingga tidak ada lagi perhitungan konvensional karena perhitungan telah bersifat objektif. Pengunaan metode AHP pada pembobotan kriteria dimana tingkat konsistensi kurang dari $10 \%$ dan nilai indeks konsistensi diterima sedangkan OCRA dapat membantu pondok pesantren pengambilan keputusan pemilihan santri berprestasi dari 75 data alternatif hingga mendapatkan 10 peringkat teratas yang akan mendapatkan penghargaan sehingga tidak memakan waktu yang lama dalam proses penilaian. Dimana nilai OCRA yang didapat berupa nilai $P_{i}$ yang di rangking untuk mendapatkan santri berprestasi yang tepat.

\section{REFERENSI}

Agustina, F., Sumpala, A. T., \& Arysespajayadi, A. (2021). SPK Pemilihan Jurusan Siswa Baru Menggunakan Metode AHP dan MOORA Pada SMKN 1 Kolaka. Jurnal Sains Dan Informatika, 7(1), 87-96. https://doi.org/10.34128/jsi.v7i1.292

Amiruddin, D., Nuryani, E., \& Faturrohmah, H. (2018). Rancangan Aplikasi Sistem Pendukung Keputusan (SPK) Pengangkatan Karyawan Menggunakan Metode Simple Additive Weighting (SAW) Pada PT. Ultra Prima Plast-Flexible Packaging. Jurnal Sistem Informasi Dan Informatika, 1(01), 1-18.

Arsyad, M. (2019). Perancangan Sistem Pendukung Keputusan Pemilihan Kepala Sekolah Terbaik Tingkat Kabupaten Deli Serdang Menggunakan Metode Analytic Hierarchy Process (Ahp). Jurnal Of Informatic Pelita Nusantara, 4(2), 19-26.

Chamid, A. A., \& Murti, A. C. (2017). Kombinasi Metode AHP dan Topsis pada Sistem Pendukung Keputusan. Prosiding SNATIF, 115-119.

Handayani, R. I., \& Muzakir, A. (2018). Sistem Pendukung Keputusan Penerimaan Karyawan Dengan Menggunakan Metode Analytical Hierarchy Process (Ahp) Studi Kasus: Pt. Virtus Venturama. Jurnal PILAR Nusa Mandiri, 14(1), 43-48.

Hidayat, R., Irmayanti, A., \& Tommy, M. (2020). Implementasi Multi Factor Evaluation Process untuk Penentuan Tempat Pembuangan Akhir Berbasis Web Aplication. Edumatic: Jurnal Pendidikan Informatika, 4(2), 103-111.

Irawati, N. (2018). Penerapan Metode AHP Penerimaan Bantuan Desa Untuk Anak Berprestasi. Seminar Nasional Royal (SENAR), 1(1), 281-284.

Kundakc1, N. (2017). An Integrated Multi-Criteria Decision Making Approach for Tablet Computer Selection. European Journal of Multidisciplinary Studies, 2(5), 36-48. https://doi.org/10.26417/ejms.v5i1.p36-48

Madić, M., Petković, D., \& Radovanović, M. (2015). Selection of non-conventional machining processes using the OCRA method. Serbian Journal of Management, 10(1), 61-73. https://doi.org/10.5937/sjm10-6802

Mesran, M., Diansyah, T. M., \& Fadlina, F. (2019). Implemententasi Metode Rank Order Cendroid (ROC) dan Operational Competitiveness Rating Analysis (OCRA) dalam Penilaian Kinerja Dosen Komputer Menerapkan (Studi Kasus: STMIK Budi Darma). Prosiding Seminar Nasional Riset Information Science (SENARIS), 822-834. https://doi.org/10.30645/senaris.v1i0.89 
Hasanudin, H., Marli, Y., \& Hendriawan, B. (2018). Sistem Pendukung Keputusan Pemilihan Karyawan Terbaik Menggunakan Metode Analytical Hierarchy Process ( Studi Kasus Pada Pt . Bando Indonesia ). Seminar Nasional Teknologi Informasi Dan Multimedia, 6(3), 91-96.

Narti, N.-, Sriyadi, S., Rahmayani, N., \& Syarif, M. (2019). Pengambilan Keputusan Memilih Sekolah Dengan Metode AHP. Jurnal Informatika, 6(1), 143-150. https://doi.org/10.31311/ji.v6i1.5552

Padmowati, R. de L. E. (2009). Pengukuran Index Konsistensi dalam Proses Pengambilan Keputusan Menggunakan Metode AHP. Seminar Nasional Informatika, 1(5), 80-84.

Pane, D. H., \& Erwansyah, K. (2020). Model Prioritas Pemilihan Daerah Pembangunan Tower Telekomunikasi Berbasis Kombinasi Metode AHP dan Metode Moora. Jutisi: Jurnal Ilmiah Teknik Informatika Dan Sistem Informasi, 9(2), 11-22.

Primadasa, Y., \& Alfiarini. (2019). Sistem Pendukung Keputusan Penilaian Kinerja Karyawan Menggunakan Pembobotan Ahp Dan Moora. Cogito Smart Journal, 5(2), 159-170.

Ramadhan, A. G., \& Santika, R. R. (2020). AHP dan WP: Metode dalam Membangun Sistem Pendukung Keputusan (SPK) Karyawan Terbaik. Edumatic: Jurnal Pendidikan Informatika, 4(1), 141-150. https://doi.org/10.29408/edumatic.v4i1.2163

Rosiska, E. (2018). Penerapan Metode Analitycal Hierarchy Process (AHP) dalam Menentukan Mitra Usaha Berprestasi. Jurnal RESTI (Rekayasa Sistem Dan Teknologi Informasi), 2(2), 479-485. https://doi.org/10.29207/resti.v2i2.419

Toruan, N. T. L. (2021). Sistem Pendukung Keputusan Pemilihan Pembawa Acara Berita Terbaik Menerapkan Metode OCRA. Bulletin of Computer Science Research, 1(3), 7178. 